\title{
Possible Down Regulation of the p16 Gene Promoter in Individuals with Hepatocellular Carcinoma
}

\author{
Oranous Bashti Shiraz ${ }^{1^{*}}$, Hamid Galehdari ${ }^{1,2}$, Majid Yavarian ${ }^{3}$, Bita Geramizadeh ${ }^{4}$ \\ ${ }^{1}$ Department of Genetics, Faculty of Science, Chamran University, Ahwaz, IR Iran \\ ${ }^{2}$ Cancer Research Center, Jondishapour Medical University, Ahwaz, IR Iran \\ ${ }^{3}$ Hematology Research Center, Shiraz University of Medical Sciences, Shiraz, IR Iran \\ ${ }^{4}$ Transplant Research Center, Department of Pathology, Shiraz University of Medical Sciences, Shiraz, IR Iran
}

\section{A R T I C L E I N F O}

Article Type:

Original Article

\section{Article history:}

Received: 12 May 2011

Revised: 28 Jun 2011

Accepted: 07 Jul 2011

\section{Keywords:}

p16

Hepatocellular carcinoma

Bisulfite

Direct sequencing methylation

\section{A B S T R A C T}

Background: The p16 tumor suppressor gene is an important negative regulator of the cell cycle. Inactivation of p16, especially via promoter hypermethylation, has been found in numerous human cancers such as breast, lung, colorectal, and liver.

Objectives: To determine the role of epigenetic methylation in p16 regulation in Iranian patients with hepatocellular carcinoma (HCC).

Patients and Methods: The methylation pattern in the p16 gene promoter was analyzed by bisulfite direct sequencing in 43 paraffin-embedded formalin-fixed tissues from patients with HCC. In addition, normal specimens from liver graft donors were used as the control group.

Results: The bisulfite direct sequencing showed heterozygous hypermethylation in $13.9 \%$ of individuals with HCC. Homozygous methylation within the GC-box IV was detected in another $58.1 \%$ of the patients.

Conclusions: It is proposed that methylation, but not necessarily hypermethylation, may play a role in the down-regulation of the p16 gene promoter at least in some Iranian patients with HCC.

๑) 2011 Kowsar M.P.Co. All rights reserved.

- Implication for health policy/practice/research/medical education:

Hypermethylation in the p16 promoter region has been reported to occur frequently in several human cancers such as HCC. We highly recommend biologists and Gastroenterologists to study this article.

\section{- Please cite this paper as:}

Bashti Shiraz O, Galehdari H, Yavarian M, Geramizadeh B. Possible Down Regulation of the p16 Gene Promoter in Individuals with Hepatocellular Carcinoma. Hepat Mon. 2011;11(9):719-23. DOI: 10.5812/kowsar.1735143X.732

\section{Background}

Hepatocellular carcinoma (HCC), one of the most fatal human malignancies, is characterized by late presentation, fast progression, and limited response to therapy (1). HCC is commonly associated with the chronic liver diseases caused by infection with the hepatitis B virus

\footnotetext{
${ }^{*}$ Corresponding author at: Oranous Bashti Shiraz, Department of Genetics, Faculty of Science, Chamran University, Ahwaz, IR Iran. Tel:+98-7116351198, Fax: +98-7116310610.E-mail:Orans_genetic@yahoo.com

DOI:10.5812/kowsar.1735143X.732

Copyright $\odot 2011$, BRCGL, Published by Kowsar M.P.Co. All rights reserved.
}

(HBV) and/or the hepatitis C virus (HCV), excessive alcohol consumption, aflatoxin, and certain metabolic diseases (2-5). Inactivation of tumor suppressor genes and activation of oncogenes initiated by genetic and epigenetic differences may play an important role in carcinogenesis. The p16ink4a gene is a tumor suppressor that acts as a negative regulator of the cell cycle by binding to and inhibiting cyclin-dependent kinase 4 (CDK4) (6). Reduced expression of the p16 gene results in uncontrolled division of cells. Several mechanisms that lead to p16 inactivation have been described, including point mutations, homozygous deletions, and promoter hypermethylation (7-9), and hypermethylation of the p16 gene 
promoter has been shown to occur more frequently in HCC patients (10-12). The p16 gene promoter contains 5 GC boxes, which are termed GCI to GCV. The boxes cover a region located upstream of the translational start site from nucleotide -474 to -1 (Figure 1) (13).

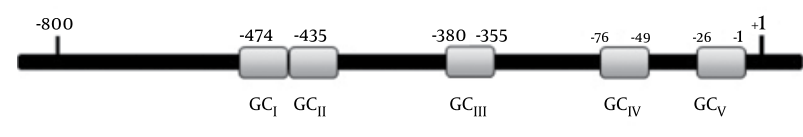

Figure 1. An 800-bp Portion of the Human p16 Gene Promoter Located Upstream of the Initiation Codon. The Promoter Region Contains 5 Consensus GC Boxes, Which are Often the Targets for Methylation-Mediated Inactivation in Diverse Human Cancers, Including HCC.

\section{Objectives}

In the present study, we used direct bisulfite sequencing in order to detect the methylation patterns of GC box IV, GC box V, and a portion of exon 1 in the p16 gene promoter in Iranian patients with HCC.

\section{Patients and Methods}

\subsection{DNA Extraction}

Paraffin-embedded formalin-fixed (PEFF) tissues from 43 patients with HCC were collected from Namazi hospital (Shiraz, Iran) between September 2005 and December 2009. For the controls, 20 normal liver tissue samples were obtained from volunteer liver graft donors. The donors were brain dead, and their families allowed their organs to be donated. Sections $(10 \mu \mathrm{m})$ were cut from the PEFF tissue blocks and were deparaffinized with xylene. Genomic DNA was extracted using a DNeasy Blood and Tissue Kit according to the manufacturer's instructions (Qiagen, Valencia, CA, USA).

\subsection{Bisulfite Modification}

Bisulfite modification was performed based on the principle that bisulfite converts unmethylated cytosine residues to uracil, whereas methylated cytosine residues remain unaffected. Therefore, after bisulfite conversion, methylated and unmethylated cytosines were determined by direct sequencing. Bisulfite treatment of DNA was performed according to the instructions in the EpiTect Bisulfite Kit (Qiagen).

\subsection{Bisulfite Direct Sequencing}

In the bisulfite direct sequencing method, primers should be designed to amplify both methylated and unmethylated sequences. In addition, they should not contain CpG- cytosines, because they are not complementary to methylated cytosines, which are not affected by sodium bisulfite. Finally, after direct sequencing, all sites with unmethylated cytosines are displayed as thymines in the amplified sense strand and as adenines in the amplified antisense strand. A 191-basepair fragment in the p16 gene promoter, including 19 CpG dinucleotides, was amplified by nested polymerase chain reaction (PCR).
The first round of amplification was performed with 100 ng of bisulfite-treated DNA. The primers for the first PCR were 5'-TTTTTAGAGGATTTGAGGGATAGG-3' (forward) and 5'-CTACCTAATTCCAATTCCCCTACAAACTTC-3' (reverse). The initial PCR conditions were as follows: $94^{\circ} \mathrm{C}$ for $1 \mathrm{~min}$; 5 cycles at $94^{\circ} \mathrm{C}$ for $45 \mathrm{~s}, 65^{\circ} \mathrm{C}$ for $45 \mathrm{~s}$, and $72^{\circ} \mathrm{C}$ for $30 \mathrm{~s} ; 5$ cycles at $94^{\circ} \mathrm{C}$ for $45 \mathrm{~s}, 64^{\circ} \mathrm{C}$ for $45 \mathrm{~s}$, and $72^{\circ} \mathrm{C}$ for $30 \mathrm{~s}$; and then 25 cycles at $94^{\circ} \mathrm{C}$ for $45 \mathrm{~s}, 63^{\circ} \mathrm{C}$ for $45 \mathrm{~s}$, and $72^{\circ} \mathrm{C}$ for 30 $\mathrm{s}$, with final extension step at $72^{\circ} \mathrm{C}$ for $5 \mathrm{~min}$. An aliquot of the PCR product was used as the template for the second (nested) PCR. The nested PCR was performed using 5'AGAAAGAGGAGGGGTTGGTTGG-3' as the forward primer and 5'-ACRCCCRCACCTCCTCTACC-3' as the reverse primer. Nested PCR was performed with an initial denaturing step at $94^{\circ} \mathrm{C}$ for $1 \mathrm{~min}$, followed by 35 cycles at $94^{\circ} \mathrm{C}$ for $45 \mathrm{~s}, 61^{\circ} \mathrm{C}$ for $45 \mathrm{~s}$, and $72^{\circ} \mathrm{C}$ for $30 \mathrm{~s}$. The subsequent cycle sequencing reaction was performed using an automatic sequencer (ABI Company).

\subsection{Statistical Analysis}

The correlation between the clinicopathological pa rameters and p16 methylation was analyzed using the Chi-square test and Student's t-test. A $P<0.05$ was considered statistically significant.

\section{Results}

A total of 43 HCC patients were analyzed according to age, sex, cirrhosis, and hepatitis and tumor pathological grade. (Table 1) Among the affected individuals, the sex ratio was 28 males to 15 females, with an average age of 48 years. Other HCC-related risk factors were as follows: cirrhosis (34.8\%), hepatitis B infection (9.3\%), and hepatitis $\mathrm{C}$ infection (2.3\%). The samples were examined pathologically and classified as well differentiated HCC ( $\mathrm{n}=$ $24)$, moderately differentiated HCC $(\mathrm{n}=14)$, and poorly differentiated HCC $(n=5)$.

A191-bp region of the p16 gene promoter in archival PEFF samples from 43 HCC cases and an additional 20 control samples prepared from normal liver tissue was subjected to bisulfite direct sequencing. We found heterozygous

\begin{tabular}{|c|c|c|}
\hline & HCC $^{\text {a }}$ Patients & Normal Controls \\
\hline $\begin{array}{l}\text { Number of cases } \\
\text { Gender }\end{array}$ & 43 & 20 \\
\hline Males & 28 & 14 \\
\hline Females & 15 & 6 \\
\hline Average age, y & 48 & 45 \\
\hline Cirrhosis & 15 & \\
\hline Hepatitis B & 4 & \\
\hline Hepatitis C & 1 & \\
\hline \multicolumn{3}{|l|}{ Grade } \\
\hline $\mathrm{Wd}^{\mathrm{a}}$ & 24 & \\
\hline $\mathrm{Md}^{\mathrm{a}}$ & 14 & \\
\hline $\mathrm{Pd}^{\mathrm{a}}$ & 5 & \\
\hline
\end{tabular}




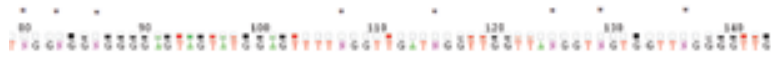

(A)

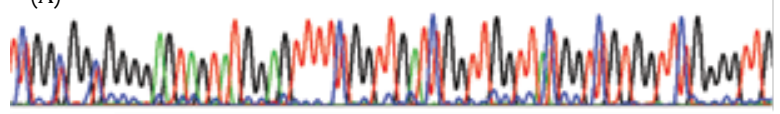

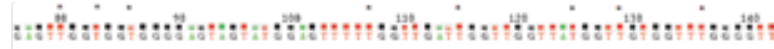

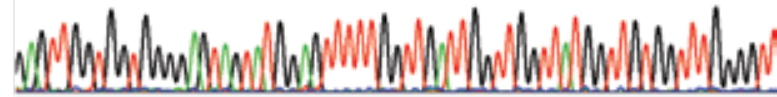

(B)

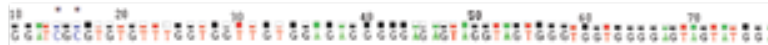

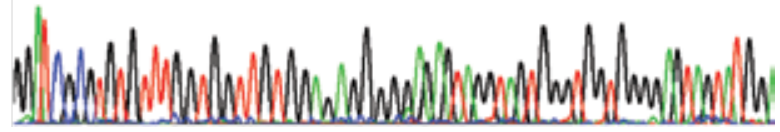

(C)

Figure 2. (A) A Portion of the p16 Gene Promoter that was Heterozygously Methylated in the HCC Samples; (B) the Same Region of the Promoter in Normal Tissues was Unmethylated. (C) A Portion of the p16 Promoter that was Methylated within GC-Box IV. Asterisks Indicate Methylated Nucleotides.

hypermethylation in $13.9 \%(n=6)$ of the HCC samples, and homozygous methylation in GC-box IV was found in 58.1\% ( $\mathrm{n}=25)$ of the HCC samples. In contrast, we did not observe any modification in the normal samples (Figure 2).

The clinical characteristics of patients who were posi- tive for hypermethylation and GC-box IV methylation are listed in Table 2. No significant correlation was found between abnormal methylation in HCC and age, gender, or tumor grade.

\section{Discussion}

DNA methylation is a type of chemical DNA modification in which a methyl group is added to carbon 5 of the cytosine ring. This reaction is carried out by a group of enzymes called DNA methyltransferases, which regulate gene transcription through DNA methylation (14). Interest in the field of DNA methylation has increased significantly in recent years because of its major role in the cancer process $(15,16)$. Aberrant methylation patterns in tumors include global hypomethylation and localized hypermethylation at $\mathrm{CpG}$ islands; however, these 2 types of epigenetic abnormalities usually seem to affect different DNA sequences. In most cancer types, genomic hypomethylation usually appears in repeated DNA sequences, while hypermethylation is most often observed within the $\mathrm{CpG}$ islands in the promoter regions of genes, frequently tumor suppressor genes (17). In this context, p16 acts as a negative regulator of the cell cycle, and hypermethylation in the p16 promoter region has been reported to occur frequently in several human cancers such as HCC (18-20). In contrast, other studies have shown a low frequency of hypermethylation within the p16 gene in individuals with HCC (21).

Table 2. Characteristics of Patients and Methylation and Hypermethylation of the p16 Gene Promoter of HCC Patients and the Control Group

\begin{tabular}{|c|c|c|c|c|c|}
\hline & $\begin{array}{l}\text { No. } \\
(n=43)\end{array}$ & $\begin{array}{l}\text { p16 Methylation/ } \\
\text { hypermethylation }(+)\end{array}$ & $\begin{array}{l}\text { p16 Methylation/ } \\
\text { hypermethylation (-) }\end{array}$ & Chi-Square & Pvalue \\
\hline \multicolumn{4}{|l|}{ Gender } & 0.02 & 0.05 \\
\hline \multirow{2}{*}{$\begin{array}{l}\text { Male } \\
\text { Female }\end{array}$} & 28 & 20 & 8 & & \\
\hline & 15 & 11 & 4 & & \\
\hline \multicolumn{6}{|l|}{ Age, y } \\
\hline $6-80$ & 43 & $49.89 \pm 5.22^{a}$ & $45.67 \pm 15.23^{a}$ & $0.46^{b}$ & $\geq 0.05$ \\
\hline \multicolumn{4}{|l|}{ Cirrhosis } & 0.99 & $>0.05$ \\
\hline \multirow{2}{*}{$\begin{array}{l}\text { Affected } \\
\text { Not affected }\end{array}$} & 15 & 8 & 7 & & \\
\hline & 28 & 19 & 9 & & \\
\hline \multicolumn{4}{|l|}{ Hepatitis B } & $0^{c}$ & $0^{c}$ \\
\hline \multirow{2}{*}{$\begin{array}{l}\text { Affected } \\
\text { Not affected }\end{array}$} & 4 & 1 & 3 & & \\
\hline & 39 & 30 & 9 & & \\
\hline \multicolumn{4}{|l|}{ Hepatitis C } & $0^{c}$ & $0^{c}$ \\
\hline \multirow{2}{*}{$\begin{array}{l}\text { Affected } \\
\text { Not affected }\end{array}$} & 1 & 0 & 1 & & \\
\hline & 42 & 31 & 11 & & \\
\hline \multicolumn{3}{|l|}{ Grade } & & 0.84 & $>0.05$ \\
\hline$W^{d}$ & 24 & 16 & 8 & & \\
\hline $\mathrm{Md}^{\mathrm{d}}$ & 14 & 11 & 3 & & \\
\hline $\mathrm{Pd}^{\mathrm{d}}$ & 5 & 4 & 2 & & \\
\hline
\end{tabular}

${ }^{\mathrm{a}}$ Mean $\pm \mathrm{SD}$

b Student's t-test

${ }^{\mathrm{c}}$ Because of the low number of samples, it was not possible to calculate a $P$ value.

d Abbreviations: Md, moderately differentiated; Pd, poorly differentiated HCC; Wd, well differentiated 
In the current study, the methylation state of the p16 gene promoter was analyzed by bisulfite direct sequencing in Iranian patients with HCC. In $13.9 \%(n=6)$ of samples, heterozygous hypermethylation was detected within the p16 gene promoter. Furthermore, DNA methylation was observed within GC-box IV in 58.1\% $(n=25)$ of tumor tissue samples. All normal samples were negative for every type of methylation tested. Therefore, we reason that methylation in GC-box IV may sufficiently decrease the transcriptional activity of the p16 gene. Several reports have suggested that methylation of at least $1 \mathrm{cy}-$ tosine would significantly down-regulate p16 promoter activity (22). In general, RNA helicase A interacts with the regulatory region of genes and facilitates transcription activity, such that methylation would significantly alter the interaction between the enzyme and the substrate (23). On the basis of the abovementioned negative results in the normal specimens, we propose that methylation, but not necessarily hypermethylation, plays a role in the down-regulation of the p16 gene promoter at least in Iranian individuals with HCC.

The methylation results have been compared to the clinicopathological features. It appears that cirrhosis is the most common risk factor for the development of HCC in our patients. Cirrhosis is a progressive disease that often leads to cancer (24). The frequency of hepatitis B (1.7-5\%) and hepatitis $\mathrm{C}(0.5-1 \%)$ infection and aflatoxin contamination could also explain the relatively high frequency of this disease in Iran (25). Among our patients, 6 were under the age of 18 years; 2 of them were affected with tyrosinemia type 1 , and 1 of them had Fanconi anemia. All of the abovementioned factors and diseases have a negative influence on liver function and thus increase the probability of HCC. For the other 3 young patients, there is a possibility that they inherited an affected gene, in particular a tumor suppressor gene. According to the 2 hit hypotheses, when an affected allele is inherited, the probability of second allele inactivation via deletion ( $\mathrm{LOH})$, mutation, and/ or promoter hypermethylation increases (26). Statistical analysis also revealed no significant correlation between the presence of abnormal methylation in the affected tissues and gender, age, and cirrhosis. Comparing p16 methylation and hypermethylation in the HCC tissues according to tumor grade, methylation or hypermethylation was detected in 16 of $24(61 \%)$ well differentiated HCCs, 11 of $14(78 \%)$ moderately differentiated HCCs, and 4 of $5(80 \%)$ poorly differentiated HCCs. Therefore, there was no association between methylation or hypermethylation and tumor grade. This indicates that methylation has a negative effect on gene expression, both in the primary stages of tumor formation and during tumor progression. Finally, we assume that other mechanisms, such as LOH and/or point mutations, might be factors responsible for tumor suppressor gene loss of function. However, additional evaluation is needed to understand the role of the epigenetic factors that influence p16, in particular, and the onset of HCC in Iranian individuals in general.

\section{Acknowledgments}

We would like to thank all of those who supported us in any respect during the completion of this project, especially the staff of the Hematology Research Center, at Nemazee Hospital in Shiraz.

\section{Financial Disclosure}

None declared.

\section{Funding/Support}

None declared.

\section{References}

1. Hernandez-Vargas H, Lambert MP, Le Calvez-Kelm F, Gouysse G, McKay-Chopin S, Tavtigian SV, et al. Hepatocellular carcinoma displays distinct DNA methylation signatures with potential as clinical predictors. PLoS One. 2010;5(3):e9749.

2. Somi M. Hepatocellular carcinoma. hepatmon. 2005;5(3):65-76.

3. Severi $\mathrm{T}$, van Malenstein $\mathrm{H}$, Verslype $\mathrm{C}$, van Pelt JF. Tumor initiation and progression in hepatocellular carcinoma: risk factors, classification, and therapeutic targets. Acta Pharmacol Sin. 2010;31(11):1409-20.

4. Wang Y, Liu H, Zhou Q, Li X. Analysis of point mutation in site 1896 of HBV precore and its detection in the tissues and serum of HCC patients. World J Gastroenterol. 2000;6(3):395-7.

5. Liu Y, Wu F. Global burden of aflatoxin-induced hepatocellular carcinoma: a risk assessment. Environ Health Perspect. 2010;118(6):818-24.

6. Serrano M, Hannon GJ, Beach D. A new regulatory motif in cell-cycle control causing specific inhibition of cyclin D/CDK4. Nature. 1993;366(6456):704-7.

7. Matsuda Y. Molecular mechanism underlying the functional loss of cyclindependent kinase inhibitors p16 and p27 in hepatocellular carcinoma. World J Gastroenterol. 2008;14(11):173440.

8. Zhang J, Lai MD, Chen J. Methylation status of p16 gene in colorectal carcinoma and normal colonic mucosa. World $J$ Gastroenterol.1999;5(5):451-4.

9. Biden K, Young J, Buttenshaw R, Searle J, Cooksley G, Xu DB, et al. Frequency of mutation and deletion of the tumor suppressor gene CDKN2A (MTS1/p16) in hepatocellular carcinoma from an Australian population. Hepatology. 1997;25(3):593-7.

10. Csepregi A, Ebert MP, Rocken C, Schneider-Stock R, Hoffmann J, Schulz HU, et al. Promoter methylation of CDKN2A and lack of p16 expression characterize patients with hepatocellular carcinoma. BMC Cancer. 2010;10:317.

11. Baek MJ, Piao Z, Kim N-G, Park C, Shin E-C, Park J-H, et al. p16 is a major inactivation target in hepatocellular carcinoma. Cancer. 2000;89(1):60-8.

12. Wong IH, Lo YM, Zhang J, Liew CT, Ng MH, Wong N, et al. Detection of aberrant p16 methylation in the plasma and serum of liver cancer patients. Cancer Res. 1999;59(1):71-3.

13. Wu J, Xue L, Weng M, Sun Y, Zhang Z, Wang W, et al. Sp1 is essential for p16 expression in human diploid fibroblasts during senescence. PLoS One. 2007;2(1):e164.

14. Reik W, Dean W. DNA methylation and mammalian epigenetics. Electrophoresis. 2001;22(14):2838-43.

15. Jones PA. DNA methylation and cancer. Oncogene. 2002;21(35):5358-60.

16. Strathdee G, Sim A, Brown R. Control of gene expression by CpG island methylation in normal cells. Biochem Soc Trans. 2004;32(Pt 6):913-5.

17. Ehrlich M. DNA methylation in cancer: too much, but also too little. Oncogene. 2002;21(35):5400-13.

18. Narimatsu T, Tamori A, Koh N, Kubo S, Hirohashi K, Yano Y, et al. p16 promoter hypermethylation in human hepatocellular carcinoma with or without hepatitis virus infection. Intervirology. 
2004;47(1):26-31.

19. Tischoff I, Tannapfe A. DNA methylation in hepatocellular carcinoma. World J Gastroenterol. 2008;14(11):1741-8.

20. Matsuda Y, Ichida T, Matsuzawa J, Sugimura K, Asakura H. p16INK4 is inactivated by extensive CpG methylation in human hepatocellular carcinoma. Gastroenterology. 1999;116(2):394400.

21. Lin YW, Chen CH, Huang GT, Lee PH, Wang JT, Chen DS, et al. Infrequent mutations and no methylation of CDKN2A (p16) MTS1) and CDKN2B (p15/MTS2) in hepatocellular carcinoma in Taiwan. EurJ Cancer. 1998;34(11):1789-95.

22. Gonzalgo ML, Hayashida T, Bender CM, Pao MM, Tsai YC, Gonzales FA, et al. The role of DNA methylation in expression of the p19/p16 locus in human bladder cancer cell lines. Cancer Res. 1998;58(6):1245-52.

23. Myohanen S, Baylin SB. Sequence-specific DNA binding activity of RNA helicase A to the p16INK4a promoter. J Biol Chem. 2001;276(2):1634-42.

24. Garr B, Flickinger J, Lotze M. Cancer of the Liver. In: Devita V, Hellman S, Rosenberg S, editors. Cancer: Principles and Practice of Oncology. Philadelphia: Lippincott-Raven;1997. p. 1271-97.

25. Fani A, Fani I, Eshrati B, Samadian P, Fani P, Gorishi Y. screening for hepatocellular carcinoma in chronic carriers of hepatitis B and C in markazi province,iran. HepatMon. 2007;7(3):149-52.

26. Chial H. Tumor suppressor(TS) genes and the two-hit hypothesis. Nature Education. 2008;1(1) 